\title{
Relationship between Fatigue Properties and Hardness for High Hardness Steels Tempered at Several Temperatures
}

by

\section{Shizuyo KonUma* and Toru FuRUKawa*}

A study was made on the effect of hardness on fatigue properties of high strength steels. Rotating bending fatigue tests were carried out on four different carbon steels tempered at four temperatures.

The results are summarized as follows;

(1) Origin and location of fatigue fracture could be classified by hardness. (2) Even for high hardness steel showing fish eye fracture, fatigue limit was proportional to hardness under the same tempering condition. (3) Fatigue limit could be estimated as a function of hardness and tempering temperature.

Key words : Fatigue, Fatigue strength, Fatigue fracture, High strength steel, Fish eye, Defect, inclution

\section{1 緒言}

表面硬化処理は耐摩耗性や耐疲労性を向上させる有 効な方法として広く機械部品に適用され, 実用的見地 からも多くの研究が行われている.

筆者らは浸炭および高周波表面硬化した鋼の疲労特 性について研究を行い, その最適疲労強度は硬化層深 さを增し, 全硬化層深さを起点とする内部起点疲労破 壞（フイッシュアイ）から硬化層へ破壊の起点が移る 条件であり, 良好な疲労強度を得るには高硬度の硬化 層の性質が重要である事を報告した。

一般に, 硬さと疲労限度は比例関係を示すが, 高硬 度域では熱処理によって硬さや引張強さなどの静的強 度を高めてもある硬さ以上では疲労強度の改善が少な いばかりか逆に低下する. また疲労強度のバラツキが 大きいこと等から高硬度鋼への信頼性は低い。それら に影響を与える因子として久陥に対する感受性, 残留 応力, 残留ひずみや金属組織などがあげられているが, 疲労破壊が介在物などを起点とする内部起点破壊とな る場合が多いので介在物の影響について種々の角度か らの検討がなされでいる.

しかし， $500^{\circ} \mathrm{C}$ 以下で焼もどしをした高硬度鋼の疲 労特性に関する系統的な報告は少ない．またこの種の 研究では試料の硬さを焼もどし温度を変えて変化させ ているが，そのような方法では硬さと共に組織や残留 応力・残留ひずみなども変化してしまい, 硬さの影響 を評価するのに適切でないと考える.

筆者らは先に組織を $150^{\circ} \mathrm{C}$ 焼もどしマルテンサイ
トにそろえ，硬さを Hv 600 ～ 800 にした 5 種類の炭 素鋼について実験し, 疲労強度抢よび破面様相を硬さ について検討した，疲労限度を規定する破壊様式は全 て内部起点であったが, 疲労限度と硬さは比例関係を 示し, 硬さを焼もどし温度で変化させた場合とは異な る結果が得られた事を報告した。

今回は硬さを焼もどし温度と炭素量により変化させ た試料について実験を行い, 高硬度鋼の疲労強度と破 壊様式に及ぼす硬さの影響について検討した。

\section{2 実 験 方 式}

本実験に用いた材料は市販の機械構造用炭素鋼 $\mathrm{S} 25 \mathrm{C} ， \mathrm{~S} 35 \mathrm{C} ， \mathrm{~S} 45 \mathrm{C}$ と $\mathrm{S} 55 \mathrm{C}$ の 4 種類の圧延丸棒で, 試験片形状は平行部直径 $9 \mathrm{~mm}$ の回転曲げ度労試験片 である。

焼入れは脱炭や熱処理変形の少ない高周波焼入法を 採用し, 周波数 $20 \mathrm{kHz}$ と出力 $33.6 \mathrm{~kW}$ を一定にして, 同一形状で送り速度を変化させて試焼きを行い, 中心 部まで一様なマルテンサイト組織となる条件を選んだ. $\mathrm{S} 25 \mathrm{C}$ は 1 回の焼入れではフェライトが残留したので 同じ条件で 2 回焼入れを行った. その後の熱処理は焼 入のまま, 焼もどし温度 $220^{\circ} \mathrm{C}, 350^{\circ} \mathrm{C}$ と $450^{\circ} \mathrm{C}$ の 4 種類である.S45C の焼もどしによる組織変化を Fig. 1 に示す．針状組織を示し， $350^{\circ} \mathrm{C}$ 以上では針状組織 に沿った炭化物の析出が認められる. なお，写真中の 記号は Table I のようである.

Table I に各鋼の炭素量, 硬さと旧オーステナイト 粒径を示す. 硬さは疲労試験後, 測定荷重 $300 \mathrm{~g}$ で測 

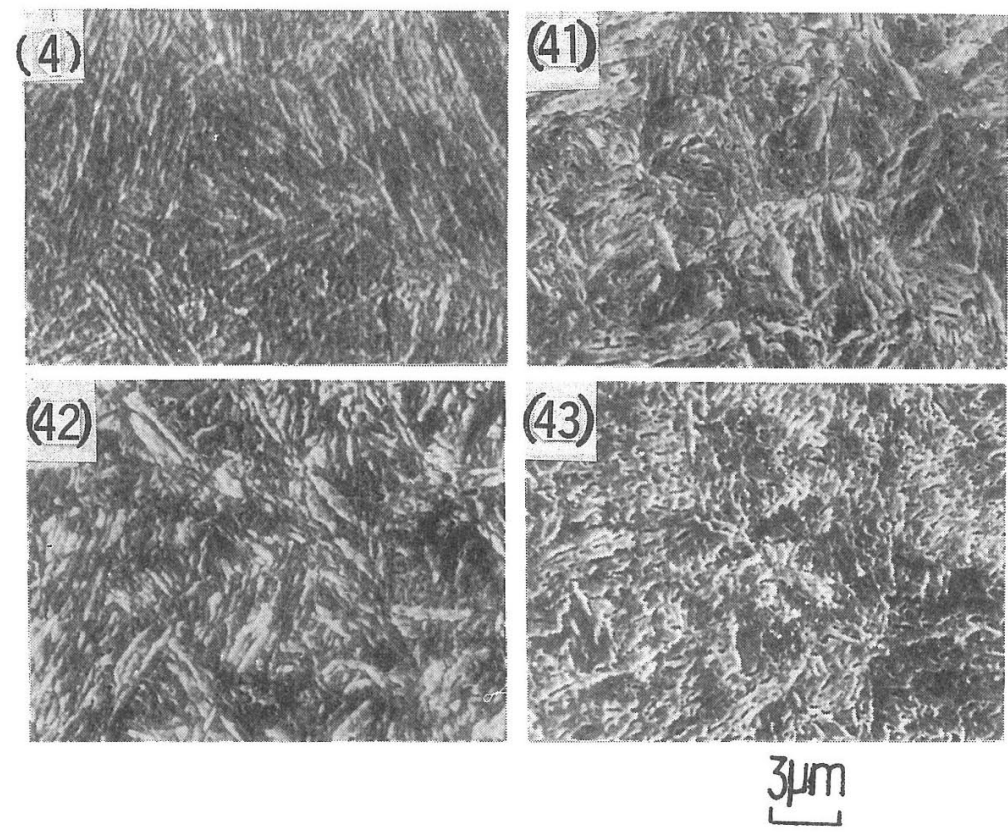

4 ; as quenched $\quad 41$; tempered at $220^{\circ} \mathrm{C}$

42 ; tempered at $350^{\circ} \mathrm{C} \quad 43$; tempered at $450^{\circ} \mathrm{C}$

Fig. 1. Microstructure of S45C steel.

Table I. C \%, hardness and prior austenite grain size of specimens used.

\begin{tabular}{|c|c|c|c|c|c|c|c|c|c|}
\hline & \multicolumn{2}{|c|}{$\mathrm{S} 25 \mathrm{C}$} & \multicolumn{2}{|c|}{$\mathrm{S} 35 \mathrm{C}$} & \multicolumn{2}{|c|}{$\mathrm{S} 45 \mathrm{C}$} & \multicolumn{2}{|c|}{$\mathrm{S} 55 \mathrm{C}$} \\
\hline & & Code & $\mathrm{Hv}$ & Code & $\mathrm{Hv}$ & Code & $\mathrm{Hv}$ & Code & $\mathrm{Hv}$ \\
\hline \multirow{4}{*}{ 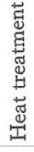 } & as quenched & 2 & 535 & 3 & 625 & 4 & 741 & 5 & 798 \\
\hline & $220^{\circ} \mathrm{C} 1 \mathrm{hr}$ Temp. & 21 & 525 & 31 & 602 & 41 & 645 & 51 & 702 \\
\hline & $350^{\circ} \mathrm{C} 1 \mathrm{hr}$ Temp. & 22 & 413 & 32 & 437 & 42 & 488 & 52 & 533 \\
\hline & $450^{\circ} \mathrm{C} 1 \mathrm{hr}$ Temp. & 23 & 335 & 33 & 334 & 43 & 377 & 53 & 400 \\
\hline \multicolumn{2}{|c|}{ Carbon (wt \%) } & \multicolumn{2}{|c|}{0.24} & \multicolumn{2}{|c|}{0.33} & \multicolumn{2}{|c|}{0.43} & \multicolumn{2}{|c|}{0.56} \\
\hline \multicolumn{2}{|c|}{ Grain size $(\mu \mathrm{m})$} & \multicolumn{2}{|c|}{17} & \multicolumn{2}{|c|}{14} & \multicolumn{2}{|c|}{13} & \multicolumn{2}{|c|}{14} \\
\hline
\end{tabular}

定した。各試料の值は測定した $11 \sim 6$ ヶの試験片の 平均值であり，個体差は最も硬い $\mathrm{S} 55 \mathrm{C}$ の焼入材で 最も大きくて Hv 750 ～ 820 であり，軟かい S25C の $450^{\circ} \mathrm{C}$ 焼もどし材では Hv $330 〜 340$ 程度であった.

表面近傍の残留応力はいずれも圧縮で $0 \sim-100$ MPa の範囲にあり, 焼もどし温度があがるにつれ減 少傾向がある.

試験片は熱処理後, 試験部を直径で約 $20 \mu \mathrm{m}$ エメ リー紙で研磨し，\#1500で仕上げてから小野式回転 曲げ疲労試験（試験機容量 $98 \mathrm{Nm}$, 回転数 3000 $\mathrm{rpm}$ ）に供した。高硬度材や表面硬化材では $10^{7}$ の繰 返し数では水平部が現われない場合が多く $10^{7}$ 回以上 の試験の必要性があると言われているが，今回は $10^{7}$ における強さをもって疲労限度を決めた。

\section{3 実 験 結 果}

\section{$3 \cdot 1$ 疲労強度について}

特徵的な $S-N$ 線図を Fig. 2 (a)〜 (c) に示す. S25C は (a)に示すように寿命 $N_{f} \geq 10^{6}$ で水平となり疲労限 度が現われる。 S45Cと S55C は(b)のように焼もど し温度により変化し, 焼入れ材と $220^{\circ} \mathrm{C}$ 材では $N_{f} \simeq 10^{6}$ を境として傾きの異なる 2 本の曲線からなる. $S-N$ 線図が折れ曲るのは疲労破壞の起点の相違によ る. 図中の/印は内部起点を示す. 高応力では表面か らき裂が発生し短寿命となるが，応力が低くなると内 部が起点となり長寿命となり $10^{7}$ の繰返し数でも水平 部は短いかほとんど現われない. $350^{\circ} \mathrm{C}$ 材と $450^{\circ} \mathrm{C}$ 材 は明確な水平部を持つ. $\mathrm{S} 35 \mathrm{C}$ の焼入れ材と $220^{\circ} \mathrm{C}$ 材 は (c) に示す様な特異な $S-N$ 線図となった.デー ターは著しく分散しているが起点位置で区分すると表 面起点と内部起点のそれぞれで別々の曲線が得られた。 同じ応力域において，き裂発生の原因となるもの（い ずれも介在物）が内部にあれば破壊までの寿命が長く， 表面にあれば短寿命となった。ししかし疲労限度は両者 で同じ值となり，起点位置の相違が影響を与えていな w.

$10^{7}$ 回の繰返し数で破断しなかった試験片を約 $5 \mu \mathrm{m}$ 電解研磨し, き裂を調べたが確認されなかった。

\section{$3 \cdot 2$ 疲労破壞の起点について}

疲労破壊の起点となった原因は内部起点の場合と表 面の介在物よりき裂が発生した場合において特定する ことができた。き裂の発生原因は介在物，粒界とその 他の 3 つに区分される. Fig. 3 は起点部の破面様相を 


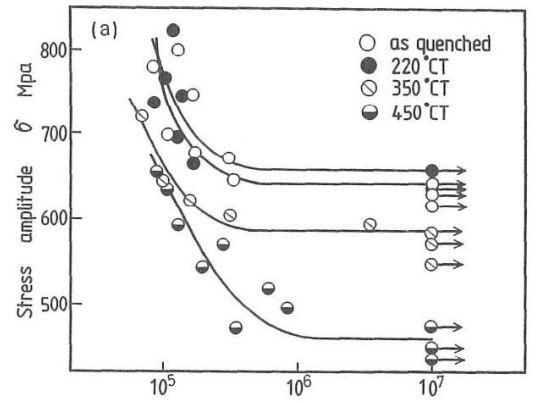

Number of cycles to failure $\mathrm{Nf}$ (a) $\mathrm{S} 25 \mathrm{C}$

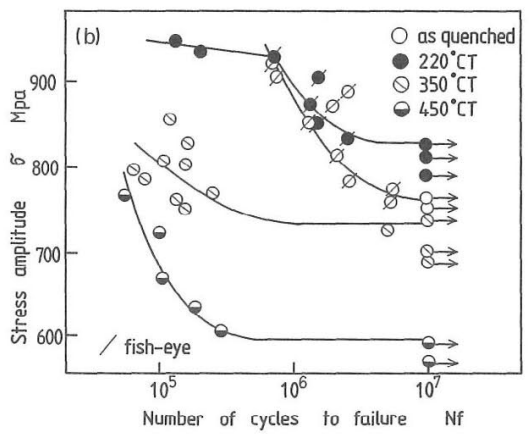

(b) $\mathrm{S} 45 \mathrm{C}$

示す. $(a)$ ( c) は介在物の例であり，大部分が $(a)(b) に$ 示す直径約 $30 \mu \mathrm{m}$ のボール状をした $\mathrm{Al}$ 系介在物であ る. (c)に示す数 $\mu \mathrm{m}$ のサイコロ状の $\mathrm{Ti}$ 系介在物も数 例あった。 介在物は母相とくさび状のすき間を持つ.

(d) は数 $\mu \mathrm{m}$ の粒界面が起点となった例である. (e)の

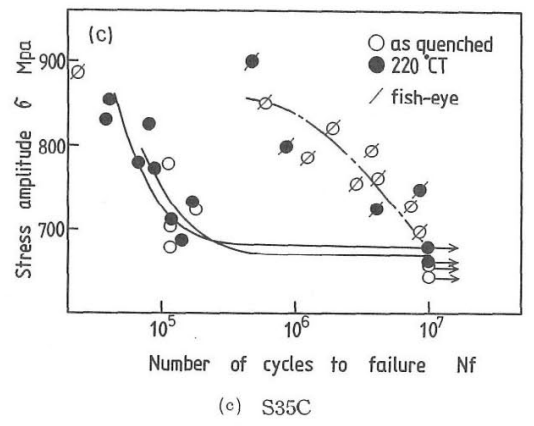

Fig. 2. $S-N$ curves.

起点部は平坦であり，XMA 分析では偏析は認められ なかった。

起点原因が特定された試料の起点深さと硬さの関係 をみると, Fig. 4 に示すように高硬度材ほど深い範囲 に及び，硬さの低下とともに浅い領域に限られ，Hv 600 付近が表面と内部起点の遷移硬さとなる.

内部起点の場合, 破断寿命と起点深さの相間関係は 認められなかった。

\section{4 実験結果の検討}

\section{4・1 疲労限度と硬さの関係……鋼種による影響}

Fig. 5 に各鋼の疲労限度と硬さの関係を示す。この 種の研究の原点となる Garwood らの結果を併せて示 す. 本実験においても，いずれの鋼にも最適硬さが存 在したが，詳細にみると比例域で硬さが同じであって も鋼種により約 $150 \mathrm{MPa}$ の幅がある。最適硬さ以上 の高硬度域における疲労限度の低下は高炭素鋼ほど大
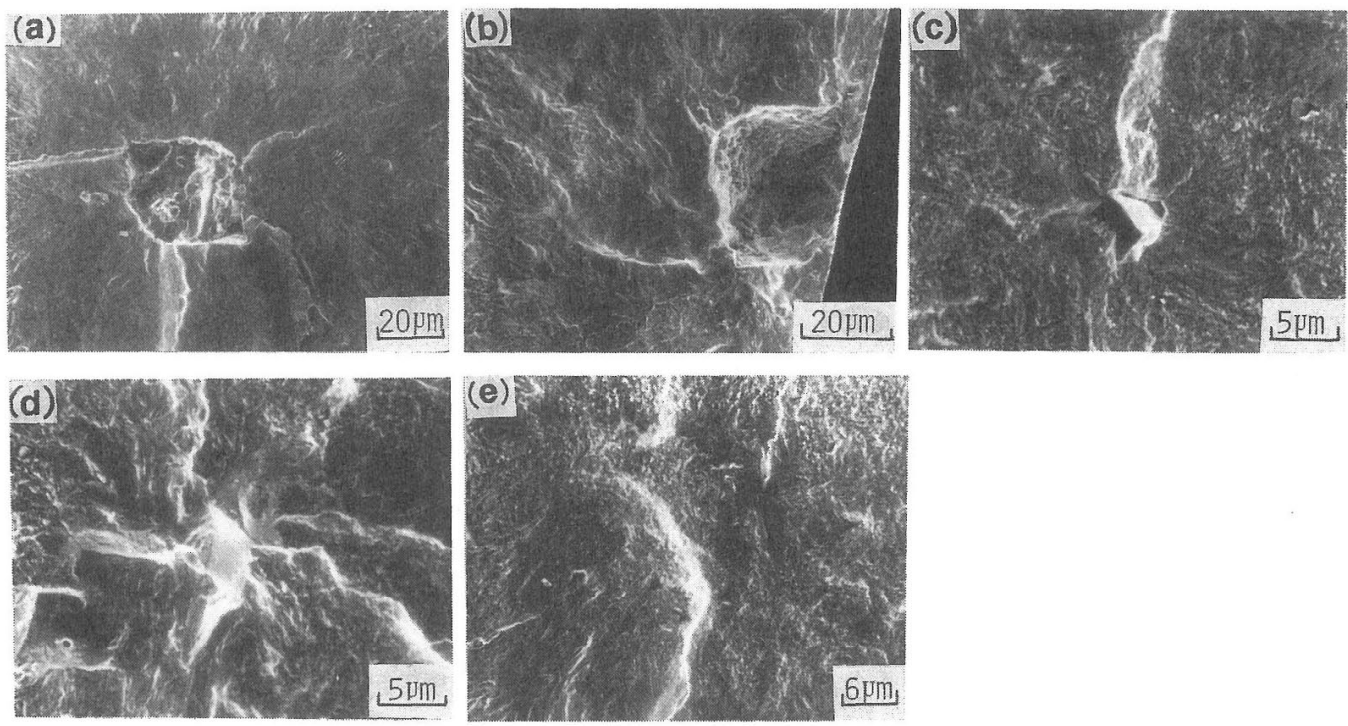
(a) (c); inclusion at center of fracture
(d) ; intergranular facet at center of fracture
(e); flat plane at center of fracture

Fig. 3. SEM micrograph of fracture origin. 


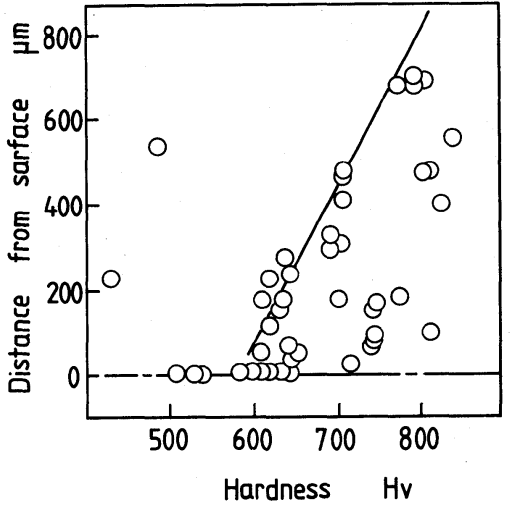

Fig. 4. Location of fracture versus hardness.

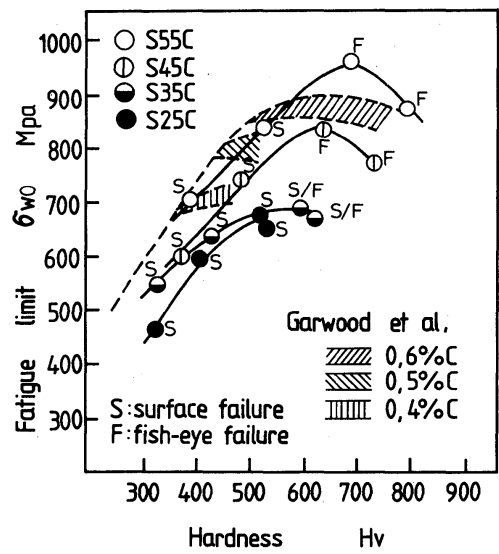

Fig. 5. Relationship between fatigue limit and hardness for several steels.

\section{きく，鋼種による影響が認められる.}

このような疲労限度の変化を破面様相の面から検討 する. Fig. 6 は起点位置区分と起点となった原因を硬 さで整理してある. 図中上部の数字は試料の記号であ る. 起点位置は Hv 600 付近を境界として表面と内部 に分けられる. 起点原因は起点位置を区分する硬さよ り高い Hv 700 が境界となり, 高硬度側は粒界型と平 坦型であり, それ以下の硬さ域では介在物が起点と なっている. 高硬度域において疲労限度の低下が大き い $\mathrm{S} 45 \mathrm{C}$ と $\mathrm{S} 55 \mathrm{C}$ の破面様相と疲労限度の関係をみ ると最適硬さとなった $220^{\circ} \mathrm{C}$ 材 $(41,51)$ は介在物が 起点となり, Hv 700 以上の硬さをもち疲労限度が低 下した焼入れ材 $(4,5)$ は粒界が起点となり介在物の 例はなく，両者で起点原因が異なった．これは焼入れ による硬度上昇が大きい中・高炭素鋼では介在物の大 きさと共に焼入れにより生じた介在物や粒界近傍での 微視的応力やひずみの大きさと焼もどしによる解放と のバランスで起点原因が決まり, 微視的応力ゃひずみ の解放が不十分な焼もどし段階では介在物よりも粒界 がより危険となる. 介在物寸法が $30 \mu \mathrm{m}$ 程度であっ

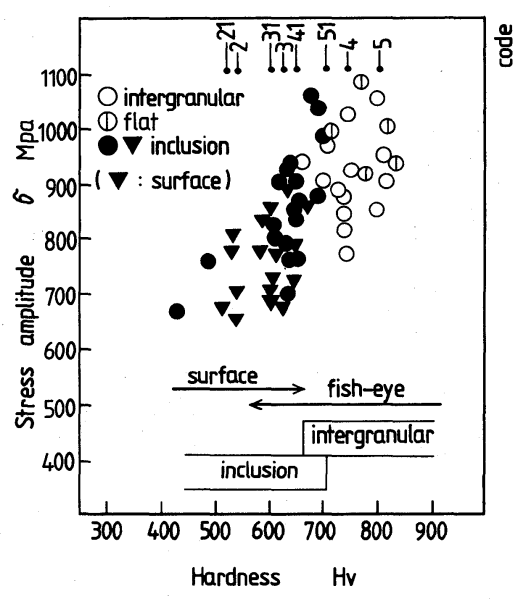

Fig. 6. Arrangement by hardness about origin and location of fatigue fracture.

た本実験の場合, 高硬度域の焼入れ材では粒界を起点 とした疲労破壊が破壊限度を規定し，その結果， $220^{\circ} \mathrm{C}$ 材よりも疲労限度が低下したと考えられる.

\section{$4 \cdot 2$ 疲労限度と硬さの関係……熱処理条件の影響}

焼もどし温度をパラメー夕に疲労限度と硬さの関係 を求めると Fig. 7 のようになる. $150^{\circ} \mathrm{C}$ 焼もどし材の 結果を破線で併せて示す．いずれの焼もどし条件にお いても硬さと疲労限度は比例し, 焼もどし温度が低下 するのに伴い直線は全体に高硬度側へ移動する。

各熱処理条件での破面様相は $350^{\circ} \mathrm{C}$ 材と $450^{\circ} \mathrm{C}$ 材 はすべて表面が起点となり介在物が原因となっていな い. しかし， $220^{\circ} \mathrm{C}$ 材は介在物が起点となっているが 起点位置が S25C は表面, S45C と S55C は内部, $\mathrm{S} 35 \mathrm{C}$ は両方が存在する。焼入れ材は $\mathrm{S} 45 \mathrm{C}$ と $\mathrm{S} 55 \mathrm{C}$ が内部の粒界， S25C は表面の介在物， S35C は内部 と表面の介在物からき裂が発生している。 この様に

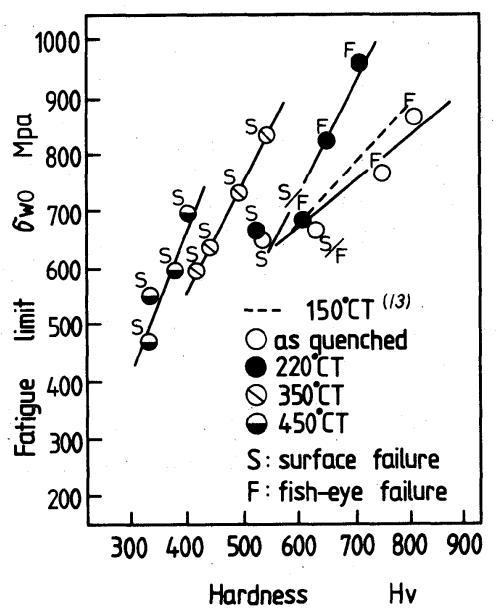

Fig. 7. Relationship between fatigue limit and hardness for several tempering temperatures. 


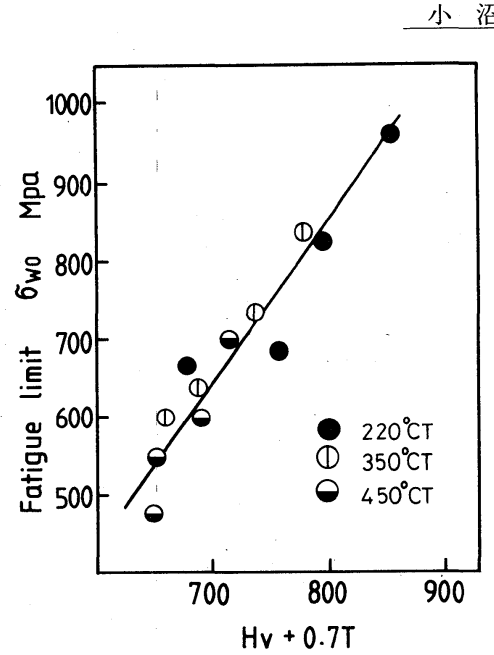

Fig. 8. Fatigue limit as function of hardness and tempering temperature.

$220^{\circ} \mathrm{C}$ 材と焼入材は鋼種により破面様相に相違がある が，熱処理条件が同じであれば表面のすべり面からき 裂が発生する低・中硬度材と同様に内部を起点とする 高硬度材に扔いても硬さの増加は疲労限度を上昇させ る.

\section{$4 \cdot 3$ 焼入れ・焼もどし材の疲労限度の推定}

疲労限度と硬さの関係を焼もどし温度をパラメータ に整理すると直線関係が成立する，その勾配 $\left(\Delta \sigma_{\mathrm{w}_{\mathrm{o}}}\right)$ $\Delta \mathrm{Hv})$ は焼入れ材が $0.833,150^{\circ} \mathrm{C}$ 材が 1.098 と焼もど し温度が高くなると共に大きくなるが，焼もどし温度 $220^{\circ} \mathrm{C} \sim 450^{\circ} \mathrm{C}$ での変化は小さく $1.960 \sim 2.332$ と近 似した值となった，勾配が近い值となった $220^{\circ} \mathrm{C}$ 〜 $450^{\circ} \mathrm{C}$ 焼もどし材について硬さと焼もどし温度を因子 として疲労限度の整理を試みた．焼もどし温度低下に 伴う高硬度側への移動量は焼もどし温度に反比例し, 硬さと焼もどし温度を加味した $\mathrm{Hv}+0.7 T$ （ $T$; 焼も どし温度， ${ }^{\circ} \mathrm{C}$ ) で疲労限度を整理すると Fig. 8 のよ うになり, 焼もどし温度 $220^{\circ} \mathrm{C} \sim 450^{\circ} \mathrm{C}$ の範囲では 1 本の直線で整理できた。

本研究では疲労限度を $10^{7}$ 回の繰返し数に扔ける強 さとし，硬さとの関係を検討したが，低・中硬度材は 疲労限度を規定する破壊様式が表面を起点とするもの であり， $S-N$ 線図は水平部を持ち, 疲労限度が現わ れるのに対し, 内部起点の高硬度材は $10^{7}$ 回の繰返し 応力でも水平部が現われなかった。 このような相違は 両者で同質の疲労特性を論じていない㧍それがある.

今後, 内部起点の疲労破壊機構の解明が必要とされ
る.

5 結 論

高硬度鋼の疲労特性に及ぼす硬さの影響を明らかに する目的で，焼もどし温度を変化させた 4 種類の炭素 鋼について回転曲げ度労試験を行い，次の結論を得た。

(1) 疲労破壊の起点位置と起点となった原因が硬さ で区分できた．Hv 600 が起点位置が表面と内部の, Hv 700 が粒界と介在物の遷移硬さとなった.

（2）焼もどし条件が同じであれば，内部起点破壊と なる高硬度域においても硬さと疲労限度は比例した。

(3) 焼もどし温度 $220^{\circ} \mathrm{C} \sim 450^{\circ} \mathrm{C}$ の範囲において 硬さに焼もどし温度を加味した因子を用いる事により 疲労限度は鋼種の影響を受けないで 1 本の直線で整理 できた.

（昭和63年12月 8 日 第19回疲労シンポジウムにて講演）

\section{参 考 文 献}

1 ) 日本機械学会編, 金属材料疲れ強さの設計資料 II (1984).

2 ）古川 徹，小沼静代，酒庭秀康，春谷 忠，鉄と鋼， 66, 410 (1980).

3 ）古川 徹, 小沼静代, 鈴木賢治, 若林 豊, 材料, 37, 178 (1980).

4 ) M. F. Garwood, M. Gensamer, H. H. Zurburg, J. T. Burwell, M. A. Erickson and F. L. Laque, "Interpretation of Test and Correlation with Service", 1 (1951) ASM.

5 ) J. Morrow, G. R. Halford, J. E. Millan, Pro, lst. Int, Cont, Fract, 2, 1611 (1966).

6 ) 西谷弘信, 緒方隆志, 遠藤正浩, 日本機械学会論文集, A -50, 1104 (1984).

7 ) 木村和夫, 山田邦博, 清水真佐男, 国尾 武, 日本機械 学会論文集, 37, 1475 (1973).

8 ）川田雄一，児玉昭太郎，日本材料強度学会誌， 6, 1 (1970).

9 ) 増田干利, 西島 敏, 田中義久, 日本機械学会論文集, A -52, 847 (1986).

10）毎熊宏則, 清水真佐男, 川嵩一博, 日本機械学会論文集, A -53，11 (1987).

11）村上敬宣，児玉昭太郎，小沼静代，日本機械学会論文集, A -54, 688 (1988).

12）村上敬宣, 清水真佐男, 日本機械学会論文集, A-54, 413 (1988).

13）小沼静代, 古川 徹, 第18回疲労シンポジウム講演論文 集, 5 (1986). 